\title{
ASSESSING GENETIC DIVERSITY AND DEMOGRAPHIC HISTORY OF THE MANCHURIAN WAPITI (CERVUS CANADENSIS XANTHOPYGUS) POPULATION IN THE GAOGESITAI, INNER MONGOLIA, CHINA
}

\author{
TIAN, X. M. ${ }^{1,2}-$ YANG, M. ${ }^{1}-$ ZHANG, M. H. ${ }^{1}-$ WANG, X. L. ${ }^{1 *}$

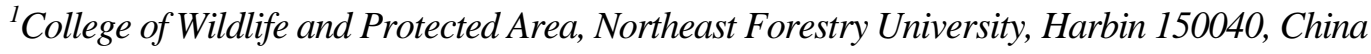 \\ ${ }^{2}$ College of Life Science and Technology, Mudanjiang Normal University, Mudanjiang 157011, China \\ *Corresponding author \\ e-mail: yttuhh@yeah.net; phone: +86-138-3614-2920
}

(Received 30 ${ }^{\text {th }}$ Mar 2020; accepted $10^{\text {th }}$ Jul 2020)

\begin{abstract}
This paper attempts to assess the genetic diversity and demographic history of the Manchurian wapiti (MW) population in the Gaogesitai region of Inner Mongolia, Northeast China. To this end, a survey was conducted on 108 stool samples collected in the Gaogesitai region. Then, the mitochondrial cytochrome b and 10 microsatellite loci were used to perform the species identification and individual identification, and $49 \mathrm{MW}$ individuals were found. Besides, the cytochrome $b$, control region and microsatellites were also analyzed to obtain the genetic data of the MWs. The analysis found that the MW population in the Gaogesitai region experienced a recent bottleneck effect, but it did not have a significant impact on the subsequent rapid population growth; the population genetic diversity is at a medium level; gene exchange between individuals within the population is frequent, and there is no inbreeding; a high proportion (50\%) of rare haplotypes in the population was detected. Thus, it is recommended to strengthen the protection and management of the MW population in this region to avoid a sharp decline in population genetic diversity.
\end{abstract}

Keywords: genetic diversity, bottleneck, inbreeding, reintroduction, microsatellites, mitochondrial DNA, Cervus canadensis xanthopygus

\section{Introduction}

The Manchurian wapiti distributed in Northeast China is a Class II wild animal under special state protection in China (Wang, 1998) and also the main prey of the world's most endangered species, the Siberian Tiger (Panthera tigris altaica) and Northeast Leopard (Panthera pardus orientalis) (Li et al., 2001; Qi et al., 2015). Due to habitat fragmentation and illegal poaching, the abundance and distribution area of the MWs have been on a decline, and some small subpopulations in the isolated area have been formed (Xu et al., 2000; Zhang and Zhang, 2011; Zhou et al., 2015). The Wandashan area was once the highest density distribution area of the MWs in Heilongjiang Province (Chen et al., 1997), but the population in this area is now on the verge of extinction (Tian et al., 2019). Since the establishment of a nature reserve at the end of the twentieth century in the south of the Greater Khingan Range in the Gaogesitai region of Inner Mongolia, the MW population has been effectively protected. A 2007-2008 survey found that the average density of the MW in this area was $1.1 / \mathrm{km}^{2}$, with a population of nearly a thousand (Zhang et al., 2009). In the past ten years, the number has been increasing, and it is currently the region with the highest population density of wild MWs (Zhang, 2016). Therefore, this area can provide important germplasm resources for the rejuvenation of the wild MW population and the reconstruction of historical distribution areas. 
Population genetic diversity and demographic history are important indicators of species survival and utilization (Haig et al., 1990; Pinilla et al., 2018; Sinnett et al., 2018; Randone et al., 2019). Research on the conservation genetics of the MW mainly focused on the Wandashan region of Heilongjiang Province (Tian and Zhang, 2010; Tian et al., 2010, 2019; Zhang et al., 2010). The MWs in the Gaogesitai region have been studied only in quantitative surveys, intestinal parasite detection, nutrition adaptation strategies, and habitat evaluation (Zhang et al., 2009; Tao and Yan, 2014; Huang, 2015; Zhang, 2016). Therefore, using the mtDNA cytochrome $b$, control region and nuclear DNA microsatellite as molecular markers, this paper explores the genetic diversity and demographic history of the MW population in the Gaogesitai region of Inner Mongolia. This study shall provide basis for the scientific protection and management of the MWs.

\section{Materials and methods}

\section{Survey area and sample collection}

Inner Mongolia Gaogesitai-Hanwula National Nature Reserve is located at the southern foot of the Greater Khingan Range, north of Alukeerqin Banner, Chifeng City, Inner Mongolia. It has geographical coordinates $44^{\circ} 41^{\prime} 03^{\prime \prime}-45^{\circ} 08^{\prime} 44^{\prime \prime} \mathrm{N}, 119^{\circ} 03^{\prime} 30^{\prime \prime}-119^{\circ} 39^{\prime} 08^{\prime \prime} \mathrm{E}$, with a total area of $1,062.8 \mathrm{~km}^{2}$ (Fig. 1). The area belongs to the middle and low mountains and hilly valley terrain, with an altitude of $900-1500 \mathrm{~m}$. It is in a middle temperate and semi-arid continental monsoon climate zone, with the annual average temperature of $3.8^{\circ} \mathrm{C}$, the frost-free period of $115 \mathrm{~d}$, the annual precipitation $437.3 \mathrm{~mm}$, the annual evaporation $1958.1 \mathrm{~mm}$, and a long and cold winter. Winter is from December to February of the following year, with the average temperature of $-7.5-15.0^{\circ} \mathrm{C}$. January is the coldest, with the average temperature of $-16^{\circ} \mathrm{C}$, the extreme low temperature of $-42^{\circ} \mathrm{C}$. In winter, the average snow cover of $30 \mathrm{~d}$, and the longest snow cover of $100 \mathrm{~d}$. The reserve is located in the northeast, north China, and Inner MongoliaXinjiang intersection area, as a typical forest-grassland interlaced zone. The diverse plant resources provide suitable habitat conditions for the MWs.

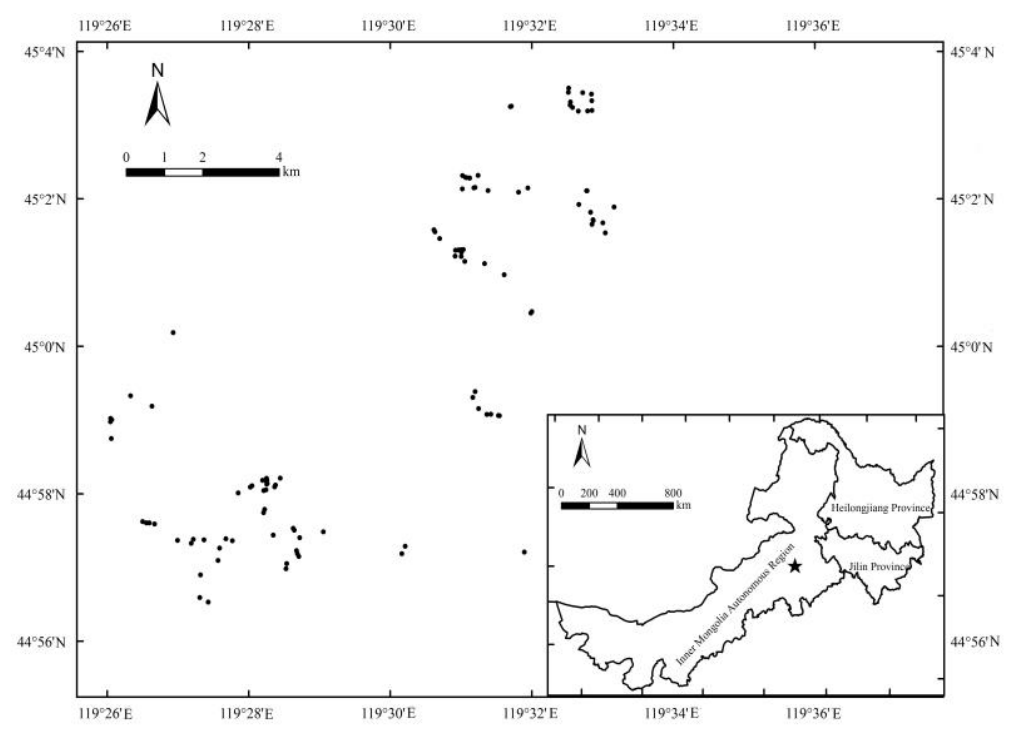

Figure 1. Sampling location of the Manchurian wapiti in the Gaogesitai, Inner Mongolia, China 
During the winter of 2017 and 2018, stools of wild MWs were collected from the entire area of the reserve as samples. The stools were found along the fresh footprint chain of the wapiti on the snow, and placed in a sealed bag for GPS (G120BD, UniStrong Inc., China) positioning. Then, another fresh footprint chain was selected for further sampling. A total of 108 stool samples were collected (Table Al), and stored frozen at $-20^{\circ} \mathrm{C}$.

\section{DNA extraction and species identification}

Stool DNA was extracted using the QIAamp DNA Stool Mini Kit (Qiagen, Germany) according to the operating manual. Select mitochondrial cytochrome b primer L14724: 5 '-CGA GAT CTG AAA AAC CAT CGT TG-3'; H15149: 5 '-AAA CTG CAG CCC CTC AGA ATG ATA TTT GTC CTC A-3' (Kocher et al., 1989; Irwin et al., 1991) for PCR amplification of stool DNA. Amplification system $50 \mu \mathrm{l}: 1 \mathrm{U} / \mu \mathrm{l}$ KOD FX Neo DNA polymerase (Toyobo, Japan) for $1 \mu 1,2 \times$ Buffer for KOD FX Neo $25 \mu 1,2 \mathrm{mmol} / \mathrm{L}$ dNTPs $10 \mu \mathrm{l}, 10 \mu \mathrm{mol} / \mathrm{L}$ L14724, H15149 1.5 each $\mu \mathrm{l}, 10-30 \mathrm{ng} / \mu \mathrm{l}$ DNA $2 \mu \mathrm{l}$, and PCR grade water (Tiangen, China) $9 \mu$ l. Reaction conditions: pre-denaturation at $94^{\circ} \mathrm{C}$ for $2 \mathrm{~min}$; denaturation at $98^{\circ} \mathrm{C}$ for 10 , annealing at $59^{\circ} \mathrm{C}$ for $30 \mathrm{~s}$, extension at $68^{\circ} \mathrm{C}$ for $30 \mathrm{~s}, 35$ cycles; then, extension at $68^{\circ} \mathrm{C}$ for $10 \mathrm{~min}$, and storage at $4^{\circ} \mathrm{C}$. The PCR products were sent to Shanghai Shengong Biological Company for purification and two-way sequencing. The SeqMan, MegAlign, and EditSeq programs in DNAStar software (DNAStar Inc., America) were used for splicing, alignment, and correction of the forward and reverse sequences. Finally, a Blast comparison was performed in the NCBI database to determine the species source of the stools.

\section{Individual identification and mitochondrial control region amplification}

10 pairs of microsatellite primers (T507, T530, T501, C143, T156, BM848, N, OCAM, DM45, ETH225) were obtained from published research results and adapted for application to wapiti (Tian et al., 2010; Zhang, 2010; Hu et al., 2018; Yang et al., 2019). The primers were used to identify the individual DNA of the MW stool, and the 5' end of the upstream primer in each microsatellite locus was fluorescently labeled (Table 1). Amplification system $20 \mu \mathrm{l}$ : 1 $\mathrm{U} / \mu 1 \mathrm{KOD}$ FX Neo DNA polymerase (Toyobo, Japan) for $0.4 \mu \mathrm{l}, 2 \times$ Buffer for KOD FX Neo $10 \mu \mathrm{l}, 2 \mathrm{mmol} / \mathrm{L}$ dNTPs $4 \mu \mathrm{l}, 10 \mu \mathrm{mol} / \mathrm{L}$ upstream and downstream primers $0.6 \mu \mathrm{l} \mathrm{each,} \mathrm{10-30}$ $1 \mu \mathrm{l}$ of ng/ $\mu \mathrm{l}$ DNA $1 \mu \mathrm{l}$, and PCR grade water (Tiangen, China) $4 \mu \mathrm{l}$, while other reaction conditions were the same as the method of species identification. A multi-tube PCR amplification protocol was used, with 3 to 7 positive PCR amplifications per locus to determine the final genotype (Taberlet et al., 1996). The 10 loci were divided into two detection systems: T507, T530, T501, C143, and T156 loci; BM848, N, OCAM, DM45, and ETH225 loci. The mixed PCR products were scanned on the ABI 3730XL sequencer (Applied Biosystems Inc., America) and allele sizes were read. The software Excel microsatellite tool kit (Park, 2001) was used to find matching genotypes in the data. The principles for judging that different samples come from the same individual are: 1) The genotypes are the same at all loci; 2) Only one allele at one locus varies (Bellemain et al., 2005). When using primers L-Pro: CGT CAG TCT CAC CAT CAA CCC CCA AAG C; H-Phe: GGG AGA CTC ATC TAG GCA TTT TCA GTG (Douzery and Randi, 1997) to amplify the entire sequence of stool DNA mitochondrial control region of different individuals at the annealing temperature of $55^{\circ} \mathrm{C}$, the amplification system and other amplification conditions are the same as the species identification method. All primer synthesis and sequencing were completed by Shanghai Biotech Biotechnology. 
Table 1. Details of 10 microsatellite loci used for the study

\begin{tabular}{|c|c|c|c|c|}
\hline Locus & Primer sequence (5'-3') & Allele length (bp) & Repeat type & Annealing temperature $\left({ }^{\circ} \mathrm{C}\right)$ \\
\hline $\mathrm{T}^{5} 07^{1}$ & $\begin{array}{l}\text { F: aggcagatgcttcaccatc } \\
\text { R: tgtggagcacctcacacat }\end{array}$ & $144-176$ & 4 & 56.6 \\
\hline $\mathrm{T} 530^{1}$ & $\begin{array}{l}\text { F: gtcctcacagcagctctatg } \\
\text { R: gcattctttagaactccaactg }\end{array}$ & $244-292$ & 4 & 55 \\
\hline $\mathrm{T} 501^{2}$ & $\begin{array}{l}\text { F: ctcctcattattaccctgtgaa } \\
\text { R: acatgctttgaccaagacc }\end{array}$ & $238-262$ & 4 & 55 \\
\hline $\mathrm{C} 143^{2}$ & $\begin{array}{l}\text { F: aaggagtctttcagttttgaga } \\
\text { R: ggttctgtctttgcttgttg }\end{array}$ & $152-164$ & 4 & 54 \\
\hline $\mathrm{T} 156^{4}$ & $\begin{array}{l}\text { F: tcttcctgacctgtgtcttg } \\
\text { R: gatgaataccagtcttgtctg }\end{array}$ & $135-207$ & 4 & 56.5 \\
\hline $\mathrm{BM} 848^{2}$ & $\begin{array}{l}\text { F: tggttggaaggaaaacttgg } \\
\text { R: cctctgctcctcaagacac }\end{array}$ & $350-366$ & 2 & 54.5 \\
\hline $\mathrm{N}^{3}$ & $\begin{array}{l}\text { F: tccagagaagcaaccaatag } \\
\text { R: gtgtgccttaaacaacctgt }\end{array}$ & $282-290$ & 4 & 56 \\
\hline OCAM $^{4}$ & $\begin{array}{l}\text { F: cctgactataatgtacagatccctc } \\
\text { R: gcagaatgactaggaaggatggca }\end{array}$ & $178-194$ & 2 & 54 \\
\hline DM45 ${ }^{4}$ & $\begin{array}{c}\text { F: caccgtttcttacaatctca } \\
\text { R: aggggtcaggttctcagtttctac }\end{array}$ & $440-460$ & 2 & 55.5 \\
\hline ETH $225^{2}$ & $\begin{array}{l}\text { F: gatcaccttgccactatttcct } \\
\text { R: acatgacagccagctgctact }\end{array}$ & $133-185$ & 2 & 56 \\
\hline
\end{tabular}

${ }^{1}$ Fam, ${ }^{2}$ Hex, ${ }^{3}$ Tamra, ${ }^{4}$ Rox

\section{Data analysis}

Clustal X 2.1 software (Larkin et al., 2007) was used to align the sequence of mitochondrial cytochrome $\mathrm{b}$ and control region in different individuals. DnaSP 5.10 software (Librado and Rozas, 2009) was applied to calculate the number of mutation sites $(S)$, number of haplotypes $(H)$, haplotype diversity $\left(H_{\mathrm{d}}\right)$, and nucleotide diversity $\left(P_{\mathrm{i}}\right)$, calculate the Tajima's D and Fu's Fs in the detection of neutral selection, and performs a significant test. Network 4.6 (Bandelt et al., 1999) was used to construct a median-joining network, and analyze the evolutionary relationship between haplotypes.

In addition, Microchecker 2.2.3 (van Oosterhout et al., 2004) was used to detect microsatellite loci for invalid alleles or allele deletions. Gimlet 1.3.3 (Valière, 2002) was to evaluate the individual identification probability $\mathrm{P}$ (ID) of 10 microsatellite loci. The software GenAlEx 6.0 (Peakall and Smouse, 2006) calculated the number of alleles $\left(N_{\mathrm{a}}\right)$, the number of effective alleles $\left(N_{\mathrm{e}}\right)$, the observed heterozygosity $\left(H_{\mathrm{o}}\right)$, the expected heterozygosity $\left(H_{\mathrm{e}}\right)$, and the fixed coefficient $\left(F_{\text {is }}\right)$. The Excel microsatellite tool kit (Park, 2001) was applied to calculate the polymorphic information content $(P I C)$. The software Genepop 4.0 (Raymond and Rousset, 1995) was to measure whether the population and each locus were in line with Hardy-Weinberg equilibrium, and also tested the linkage disequilibrium between each locus. The Markov chain method was used in the probability test, setting the parameters to 10,000 de-memorization, 20 batches, and 5,000 iterations. Hardy-Weinberg equilibrium and linkage disequilibrium tests all used the Bonferroni method to correct the significance. Bottleneck 1.2 (Piry et al., 1999) tested whether the population has recently experienced bottleneck effects. The Wilcoxon test was performed under a two-phase model (TPM) and a stepwise mutation model (SMM), and repeated 1,000 times, of which TPM is considered the most suitable model for microsatellite analysis (Ellegren, 2004). This is because TPM selected $79 \%$ of the mutations to comply with SMM, and the coefficient of variation was 9\% (Piry et al., 1999). Structure 2.3.4 (Pritchard et al., 2000) was to analyze the genetic structure of the population, with the 
parameters setting of Length of Burn-in Period 100,000, Number of MCMC Reps after Burn-in 10,000, $K=1-6$, Number of Iterations 20. The calculation results were uploaded to Structure Harvester Web v0.6.94 (Earl and von Holdt, 2012) for analysis, and the grouping number $\mathrm{K}$ of population genetic structure was determined according to the maximum peak value of the $\operatorname{Ln} \operatorname{Pr}(\mathrm{X} \mid K)$ curve.

\section{Results}

\section{Species identification and individual identification}

The amplification products ( $425 \mathrm{bp}$ ) of Mitochondrial cytochrome b were successfully obtained in 96 of 108 stool samples. The species identification results confirmed that all 96 stool samples were from the MWs. The individual discrimination rate of 10 microsatellite loci was very high. The probability that two random individuals have the same genotype is Prod (unbias) $=1.219 \times 10^{-10}$. Even in the case of full sibs, the probability of misjudgment Prod (sibs) is only $0.033 \%$ (Fig. 2). The results of individual identification showed that 96 stool samples belonged to 49 individuals. Ten microsatellite loci were detected by Microchecker, to find no invalid alleles or allele deletions. The Hardy-Weinberg equilibrium test showed that the 10 microsatellite loci and the entire population met the Hardy-Weinberg equilibrium, and the fixed coefficient $F_{\text {is }}$ values did not significantly deviate from zero (Table 2). The probability value of linkage disequilibrium test was corrected by Bonferroni's method, which indicated no linkage disequilibrium among 10 microsatellite loci.

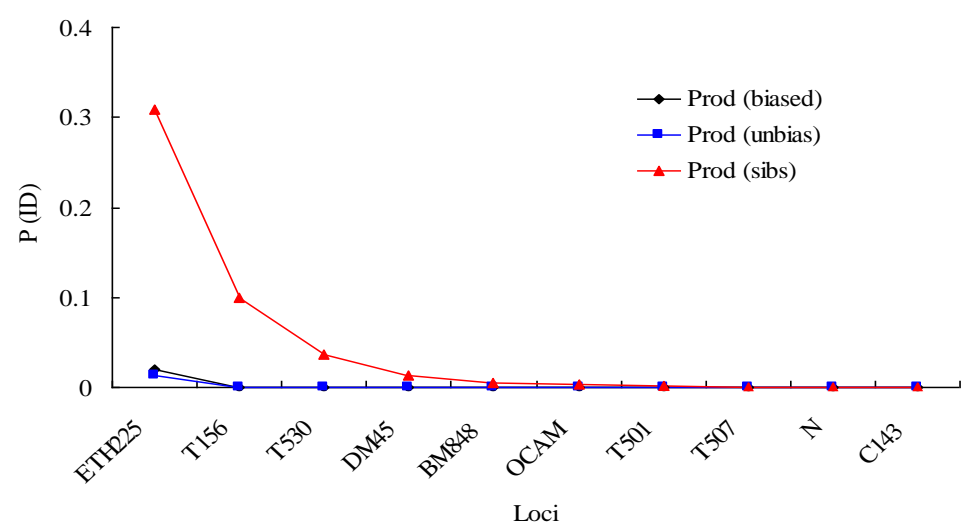

Figure 2. Decrease in probability of identity, $P(I D)$, for wapiti genotypes as more microsatellite loci were added

\section{Mitochondrial DNA sequence analysis}

A total of 4 mutation sites were found in 49 mitochondrial cytochrome b sequences (425 bp), including 3 transition sites and 1 transversion site. No insertion or deletion sites were found. The nucleotide base of the sequence was composed of $\mathrm{A}, \mathrm{T}, \mathrm{C}$, and $\mathrm{G}$, with the contents of $31.9 \%, 29.9 \%, 23.7 \%$, and 14.6\%, respectively. 4 haplotypes were detected. Among 49 individuals, the distribution frequencies of haplotypes Hap1-Hap4 were $55.1 \%, 2.0 \%, 2.0 \%$, and $40.8 \%$ (Table 3 and Fig. 3). 
Table 2. Variability parameters for the 10 microsatellite loci used in 49 individuals of the Manchurian wapiti

\begin{tabular}{c|c|c|c|c|c|c|c}
\hline Locus & $\boldsymbol{N}_{\mathbf{a}}$ & $\boldsymbol{N}_{\mathbf{e}}$ & $\boldsymbol{P I C}$ & $\boldsymbol{H}_{\mathbf{o}}$ & $\boldsymbol{H}_{\mathbf{e}}$ & $\boldsymbol{F}_{\text {is }}$ & $\boldsymbol{P}_{\mathbf{H W}}$ \\
\hline $\mathrm{T} 507$ & 6 & 2.349 & 0.520 & 0.551 & 0.574 & 0.041 & 0.242 \\
$\mathrm{~T} 530$ & 10 & 5.231 & 0.786 & 0.735 & 0.809 & 0.092 & 0.583 \\
$\mathrm{~T} 501$ & 5 & 2.813 & 0.600 & 0.735 & 0.645 & -0.140 & 0.777 \\
$\mathrm{C} 143$ & 4 & 1.415 & 0.261 & 0.347 & 0.293 & -0.183 & 0.704 \\
$\mathrm{~T} 156$ & 11 & 7.646 & 0.855 & 0.857 & 0.869 & 0.014 & 0.076 \\
$\mathrm{BM} 848$ & 7 & 3.515 & 0.679 & 0.714 & 0.716 & 0.002 & 0.745 \\
$\mathrm{~N}$ & 3 & 1.476 & 0.287 & 0.265 & 0.323 & 0.178 & 0.189 \\
OCAM & 6 & 3.210 & 0.637 & 0.703 & 0.688 & -0.022 & 0.575 \\
DM45 & 9 & 4.450 & 0.751 & 0.714 & 0.775 & 0.079 & 0.061 \\
ETH225 & 17 & 9.434 & 0.885 & 0.918 & 0.894 & -0.027 & 0.595 \\
All & 7.8 & 4.154 & 0.626 & 0.654 & 0.659 & -0.040 & 0.407 \\
\hline
\end{tabular}

$N_{\mathrm{a}}$ : number of alleles found; $N_{\mathrm{e}}$ : effective number of alleles; PIC: polymorphism information content; $H_{\mathrm{o}}$ : observed heterozygosity; $H_{\mathrm{e}}$ : expected heterozygosity; $F_{\mathrm{is}}$ : fixation index; $P_{\mathrm{HW}}$ : probability of HardyWeinberg equilibrium test

Table 3. Genetic variability at the mitochondrial cytochrome b (cyt b) and control region (CR) in the Manchurian wapiti population

\begin{tabular}{c|c|c|c|c|c|c|c}
\hline & $N$ & $S$ & $H$ & $H_{\mathrm{d}}$ & $P_{\mathrm{i}}(\%)$ & Tajima's D & Fu's Fs \\
\hline Cyt $b$ & 49 & 4 & 4 & $0.540 \pm 0.036$ & $0.359 \pm 0.106$ & 1.601 & 2.169 \\
CR & 27 & 28 & 4 & $0.385 \pm 0.108$ & $0.805 \pm 0.243$ & 0.510 & $10.573^{* *}$ \\
\hline
\end{tabular}

$N$ : number of animal individuals; $S$ : number of variable sites; $H$ : number of haplotypes; $H_{\mathrm{d}}$ : haplotype diversity; $P_{\mathrm{i}}$ : nucleotide diversity; significant of neutrality tests based on Tajima's D and Fu's Fs $\left({ }^{*} P<0.05 ;{ }^{* *} P<0.01\right)$
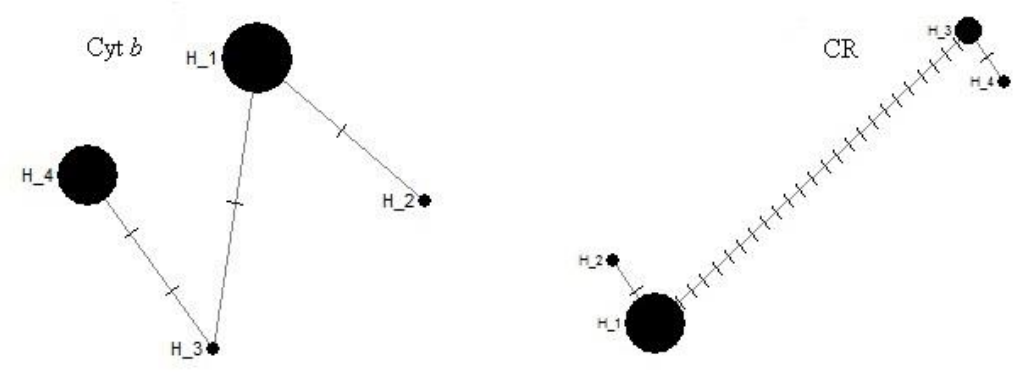

Figure 3. The haplotype networks used the median-joining method at the mitochondrial cytochrome b (cyt b) and control region $(C R)$ in the Manchurian wapiti population. The size of each circle represents the frequency of haplotypes. The nucleotide transitions and transversions are indicated by dashes

Of the 49 individual samples, 27 obtained the complete sequence of mitochondrial control region (993 bp). A total of 28 mutation sites were found, including 25 transformation sites, 2 transversion sites, and 1 insertion/deletion site. The contents of A, $\mathrm{T}$, C, and $\mathrm{G}$ were $30.2 \%, 31.8 \%, 22.2 \%$, and $15.8 \%$, respectively. 4 haplotypes were detected. Among 27 individuals, the distribution frequencies of haplotypes Hap1-Hap4 were $77.8 \%, 3.7 \%, 14.8 \%$, and $3.7 \%$ (Table 3 and Fig. 3). 


\section{Genetic diversity}

The haplotype diversity index $\left(H_{\mathrm{d}}\right)$ of the mitochondrial cytochrome $\mathrm{b}$ sequence was $0.540 \pm 0.036$, and the nucleotide diversity index $\left(P_{\mathrm{i}}\right)$ was $0.359 \pm 0.106 \%$. The $H_{\mathrm{d}}$ of the complete sequence in the mitochondrial control region was $0.385 \pm 0.108$, and the $P_{\mathrm{i}}$ was $0.805 \pm 0.243 \%$ (Table 3). Microsatellite data indicates that the average number of alleles $\left(N_{\mathrm{a}}\right)$ in the population was 7.8 and the number of effective alleles $\left(N_{\mathrm{e}}\right)$ was 4.154 , that is, the $N_{\mathrm{e}}$ at each locus is less than the $N_{\mathrm{a}}(\mathrm{P}<0.05)$. The 10 microsatellite loci had a PIC of 0.626 (0.261-0.885). Except for loci $\mathrm{C} 143$ and N, the other 8 were highly polymorphic loci $(P I C>0.5)$. The expected heterozygosity $\left(H_{\mathrm{e}}\right)$ was $0.659(0.293-0.894)$, and the average observed heterozygosity $\left(H_{\mathrm{o}}\right)$ was $0.654(0.265-0.918)$ (Table 2$)$.

\section{Demographic history}

The value of $K$ at which $\ln \operatorname{Pr}(\mathrm{X} \mid K)$ is maximized is 1 . For values $K>1$ the $\ln \operatorname{Pr}(\mathrm{X} \mid K)$ dramatically decreases and the variance between independent run increases (Fig. 4). Based on this, there is no significant genetic differentiation in the MW population in the Gaogesitai region, and gene exchange between individuals is frequent. The microsatellite population bottleneck detection concluded that neither TPM model nor SMM model showed significant excess heterozygosity $(P>0.05)$, and the allele frequency did not significantly deviate from the normal L-shaped distribution, detecting no bottleneck effect in the recent population. The neutrality test of mitochondrial cytochrome $b$ and control region showed that both Tajima's D and Fu's Fs were non-significant positive values, and only the control region $\mathrm{Fu}$ 's Fs value was significantly positive, which deviated from the neutrality hypothesis $(\mathrm{P}<0.01)$. The mtDNA test suggests that the MW population may have experienced a weak bottleneck effect recently (Table 3). Microsatellite data showed that there was no significant difference between the observed heterozygosity and expected heterozygosity of the population $(P>0.05)$, and the fixed coefficient $\left(F_{\text {is }}\right)$ was -0.040 , which did not significantly deviate from zero $(\mathrm{P}>0.05)$, and indicated that the population did not have close inbreeding (Table 2).

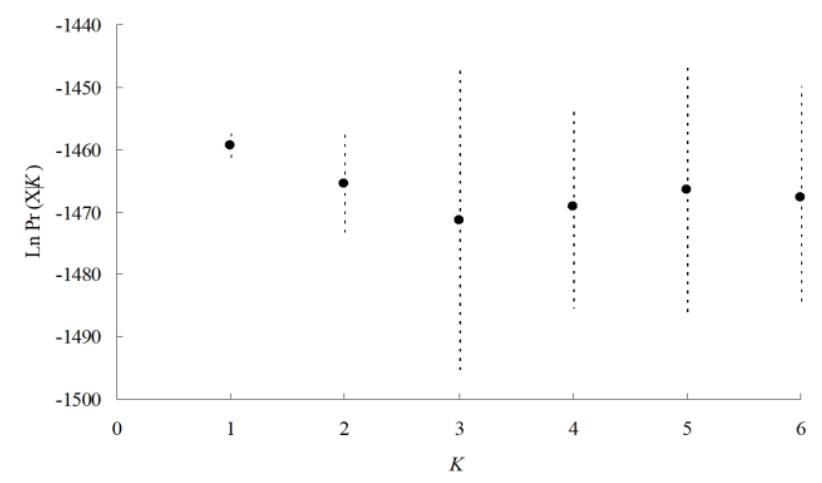

Figure 4. Plot of the likelihood of each value of $\ln \operatorname{Pr}(X \mid K)$ from twenty independent runs for $K=1-6$

\section{Discussion}

The loss of genetic diversity can lead to a decline in the ability of animals to adapt to environmental changes and even the extinction of species. The genetic diversity of populations is an important part of endangered animal protection (Frankham et al., 2010). 
Haplotype diversity $\left(H_{\mathrm{d}}\right)$ and nucleotide diversity $\left(P_{\mathrm{i}}\right)$ are key indicators to measure the degree of genetic variation of mtDNA in the population; taking into account the proportion of haplotypes in the population, the $P_{\mathrm{i}}$ value evaluates genetic diversity more accurately (Neigel and Avise, 1993; Ma et al., 2019). In this study, the $P_{\text {i }}$ value $(0.805 \%)$ of mitochondrial control region was significantly higher than that $(0.359 \%)$ of cytochrome $b$. Many animals and plants, and humans generally have a polymorphism in the non-coding region of the gene that is higher than in the coding region (Crochet and Desmarais, 2000), mainly because the non-coding control region in the mitochondrial genome evolves faster and bears less selection pressure (Krojerová-Prokešová et al., 2013; Zorigul et al., 2019). Microsatellite data showed that the average observed heterozygosity $\left(H_{\mathrm{o}}\right)$ and expected heterozygosity $\left(H_{\mathrm{e}}\right)$ of the population were 0.654 and 0.659 , respectively. Based on $P_{\mathrm{i}}$ values of mtDNA and $H_{\mathrm{e}}$ of microsatellites, the MWs were compared with other subspecies and major deer families, to find that the genetic diversity of the MW populations in the Gaogesitai region of Inner Mongolia is at a medium level (Table 4). Hap2 and Hap3 of mitochondrial cytochrome b, Hap2 and Hap4 of the control region each have only one individual, and the proportion of rare haplotypes was as high as 50\% (4/8) (Fig. 3). Therefore, it's necessary to strengthen the protection and management of the WMs in this area, and especially for the rare haplotype individuals, they must be monitored to prevent a sharp decline in genetic diversity of the population.

Table 4. Comparison of genetic variability at microsatellite loci and the mitochondrial DNA in the Cervus populations

\begin{tabular}{|c|c|c|c|c|c|c|c|c|}
\hline \multirow{2}{*}{ Species } & \multirow{2}{*}{ Region } & \multicolumn{2}{|c|}{ Microsatellite } & \multicolumn{2}{|c|}{ Control region } & \multicolumn{2}{|c|}{ Cytochrome $b$} & \multirow{2}{*}{ Author } \\
\hline & & $H_{\mathrm{o}}$ & $H_{\mathrm{e}}$ & $H_{\mathrm{d}}$ & $P_{\mathrm{i}}(\%)$ & $H_{\mathrm{d}}$ & $P_{\mathrm{i}}(\%)$ & \\
\hline $\begin{array}{l}\text { Cervus canadensis } \\
\text { xanthopygus }\end{array}$ & $\begin{array}{c}\text { Gaogesitai Reserve, } \\
\text { Inner Mongolia, China }\end{array}$ & 0.654 & 0.659 & 0.385 & 0.805 & 0.540 & 0.359 & $\begin{array}{l}\text { Tian et al. (this } \\
\text { study) }\end{array}$ \\
\hline $\begin{array}{l}\text { Cervus hanglu } \\
\text { yarkandensis }\end{array}$ & $\begin{array}{c}\text { Tarim Basin, Xinjing, } \\
\text { China }\end{array}$ & 0.083 & 0.378 & 0.693 & 1.351 & 0.845 & 1.500 & $\begin{array}{l}\text { Mahmut et al., } \\
2012 ; \\
\text { Tayerjan et al., } \\
2018\end{array}$ \\
\hline $\begin{array}{l}\text { Cervus elaphus } \\
\quad \text { elaphus }\end{array}$ & $\begin{array}{c}\text { Šumava National Park, } \\
\text { Czech Republic }\end{array}$ & 0.401 & 0.405 & 0.511 & 1.270 & - & - & $\begin{array}{l}\text { Fickel et al., } \\
2012\end{array}$ \\
\hline $\begin{array}{l}\text { Cervus elaphus } \\
\text { elaphus }\end{array}$ & $\begin{array}{l}\text { Bavarian Forest } \\
\text { National Park, } \\
\text { Germany }\end{array}$ & 0.416 & 0.459 & 0.385 & 0.974 & - & - & $\begin{array}{l}\text { Fickel et al., } \\
\quad 2012\end{array}$ \\
\hline $\begin{array}{l}\text { Cervus nippon } \\
\text { mantchuricus }\end{array}$ & $\begin{array}{c}\text { Lazovsky and Sikhote- } \\
\text { Alin Reserve, } \\
\text { Primorsky Krai, Russia }\end{array}$ & 0.617 & 0.710 & 0.446 & 0.836 & 0.285 & 0.649 & $\begin{array}{l}\text { Krojerová- } \\
\text { Prokešová et al., } \\
2013\end{array}$ \\
\hline $\begin{array}{c}\text { Cervus canadensis } \\
\text { sibiricus }\end{array}$ & $\begin{array}{l}\text { Tianshan Mountains, } \\
\text { Xinjing, China }\end{array}$ & 0.767 & 0.713 & 0.669 & 0.464 & 0.567 & 0.216 & Zhou, 2015 \\
\hline $\begin{array}{c}\text { Cervus canadensis } \\
\text { wallichii }\end{array}$ & $\begin{array}{l}\text { Sangri County, Tibet, } \\
\text { China }\end{array}$ & 0.519 & 0.719 & - & - & 0.897 & 2.781 & $\begin{array}{l}\text { Hu et al., 2018; } \\
\text { Liu and Zhang, } \\
2011\end{array}$ \\
\hline $\begin{array}{l}\text { Cervus canadensis } \\
\text { xanthopygus }\end{array}$ & $\begin{array}{l}\text { Wanda Mountains, } \\
\text { Heilongjiang, China }\end{array}$ & 0.693 & 0.737 & - & - & - & - & Tian et al., 2010 \\
\hline $\begin{array}{l}\text { Cervus elaphus } \\
\text { elaphus }\end{array}$ & $\begin{array}{c}\text { Scotland and England, } \\
\text { UK }\end{array}$ & 0.447 & 0.801 & 0.461 & 0.563 & - & - & $\begin{array}{l}\text { Hmwe et al., } \\
2006\end{array}$ \\
\hline $\begin{array}{l}\text { Cervus canadensis } \\
\text { canadensis }\end{array}$ & $\begin{array}{l}\text { Rocky Mountain, } \\
\text { Alberta, Canada }\end{array}$ & - & - & 0.932 & 0.653 & - & - & $\begin{array}{l}\text { Speller et al., } \\
2014\end{array}$ \\
\hline $\begin{array}{l}\text { Cervus canadensis } \\
\text { alashanicus }\end{array}$ & $\begin{array}{l}\text { Helan Mountains, } \\
\text { Ningxia and Inner } \\
\text { Mongolia, China }\end{array}$ & - & - & - & - & 0.243 & 0.032 & Qiao et al., 2019 \\
\hline $\begin{array}{c}\text { Cervus canadensis } \\
\text { xanthopygus }\end{array}$ & $\begin{array}{l}\text { Muling Reserve, } \\
\text { Heilongjiang, China }\end{array}$ & 0.663 & 0.712 & - & - & 0.586 & 0.305 & Liu, 2017 \\
\hline
\end{tabular}

The scientific name of the species referenced IUCN Red List of Threatened Species 2018 
Landscape pattern and species' migration ability are the most important factors affecting population genetic structure (Yuasa et al., 2007; Pérez-Espona et al., 2008). The MWs have high migration ability (Reinecke et al., 2014; Tian et al., 2019), and there are no obvious landscape barriers in the study area (Zhang, 2016), which ensures frequent gene communication between individuals, so there is no significant genetic differentiation in the population (Fig. 4). The historical bottleneck effect of the population was not detected based on microsatellite data, but the mtDNA detection showed that the MWs may have experienced a weaker bottleneck effect recently. The reason may be that maternal inherited mtDNA is more sensitive to population bottleneck effects than nuclear DNA (Krojerová-Prokešová et al., 2013). However, microsatellite data showed a significant lack of heterozygosity in the SMM model, which suggests that the population increased rapidly after the bottleneck event (Maruyama and Fuerst, 1985; Krojerová-Prokešová et al., 2013). The data of mitochondrial cytochrome $\mathrm{b}$ in this study showed that high haplotype diversity $\left(H_{\mathrm{d}} \geq 0.5\right)$ and low nucleotide diversity $\left(P_{\mathrm{i}}<0.5 \%\right)$ of the population (Table 3$)$ are also considered to be results of rapid growth and mutation accumulation after bottleneck effects (Grant and Bowen, 1998; Yuasa et al., 2007). Based on the above, this study believes that the MW population in the Gaogesitai region of Inner Mongolia has experienced a recent bottleneck effect, followed by rapid population growth. Started in the 1950s, the number of wild MWs dropped sharply due to habitat destruction and over-harvesting in the Gaogesitai region; at the end of the 20th century, the population of the area reached a historical low. At the beginning of this century, especially the establishment of nature reserves taking the MW as the key protection object has helped to restore the MW population quickly (Zhang, 2009). Compared with the lowest point in history, the number of MW populations in the study area has increased by nearly 10 times. It has become the highest density distribution area in Northeast China. This study also found that Hap3 and Hap4 in the mitochondrial control region were highly variant haplotypes, which are significantly different from other haplotypes (Fig. 3). Meanwhile, the control region sequence of the population showed low haplotype diversity $\left(H_{\mathrm{d}}<0.5\right)$ and high nucleotide diversity $\left(P_{\mathrm{i}} \geq 0.5 \%\right)$ (Table 3). Some studies believe that this is often caused by isolated populations coming into contact again (Grant and Bowen, 1998). It's known that there are often incidents such as chaotic captivity, and semi-free-range MW individuals fleeing to the wild, and these escaped individuals in contact with wild populations and genetic fusion may lead to high variant haplotypes. It may also be that the number of individuals analyzed by the mitochondrial control region is small (27), resulting in a lower haplotype diversity in the population.

\section{Conclusion}

In summary, this study shows that the genetic diversity of the MW population in the Gaogesitai region of Inner Mongolia is at a medium level, and the recently weak bottleneck effect has no significant effect on the rapid population growth. Also, gene exchange is frequent among individuals, and inbreeding is not detected. The high proportion of rare haplotypes and highly mutated haplotypes in the population indicates that research areas should continue strengthening the protection and management of MW populations to avoid a sharp decline in population genetic diversity and genetic pollution. It is suggested that the individuals with rare haplotypes should be taken as the key point in monitoring and protection, and assess the field adaptability and diseases in the field. The reintroduction projects should be carrued out at the right time, so as to improve the gene exchange between individuals and accelerate the population restoration in other areas of Northeast China. 
Acknowledgements. Our study was funded by the Heilongjiang Provincial Basic Research Business Support Project, China (1353ZD006); National Science Foundation of China (30870309); Mudanjiang Normal College Project (GP2019005, MQP201405 and QN2019009). We thank L. Q. Zhong and J. H. Guo for help given throughout this project. We acknowledge the professional staff, guides, and drivers of Inner Mongolia Gaogesitai Hanwula National Nature Reserve.

\section{REFERENCES}

[1] Bandelt, H., Forster, P., Rohl, A. (1999): Median joining networks for inferring intraspecific phylogenics. - Molecular Biology Evolution 16(1): 37-48.

[2] Bellemain, E., Swenson, J. E., Tallmon, D., Brunberg, S., Taberlet, P. (2005): Estimating population size of elusive animals with DNA from hunter-collected feces: four methods for brown bears. - Conservation Biology 19(1): 150-161.

[3] Chen, H. P., Wu, J. P., Zhang, M. H. (1997): Heilongjiang Provincial Red Deer. - Harbin: Northeast Forestry University Press.

[4] Crochet, P. A., Desmarais, E. (2000): Slow rate of evolution in the mitochondrial control region of gulls (aves: laridae). - Molecular Biology and Evolution 17(12): 1797-1806.

[5] Douzery, E., Randi, E. (1997): The mitochondrial control region of Cervidae: Evolutionary patterns and phylogenetic content. - Molecular Biology and Evolution 14(11): 1154-1166.

[6] Earl, D. A., von Holdt, B. M. (2012): STRUCTURE HARVESTER: A website and program for visualizing STRUCTURE output and implementing the Evanno method. Conservation Genetics Resources 4(2): 359-361.

[7] Ellegren, H. (2004): Microsatellites: simple sequences with complex evolution. - Nature Reviews Genetics 5(6): 435-445.

[8] Fickel, J., Bubliy, O. A., Stache, A., Noventa, T., Jirsa, A., Heurich, M. (2012): Crossing the border? Structure of the red deer (Cervus elaphus) population from the BavarianBohemian forest ecosystem. - Mammalian Biology 77(3): 211-220.

[9] Frankham, R., Ballou, J. D., Briscoe, D. A. (2010): Introduction to Conservation Genetics (2nd edition). - New York: Cambridge University Press.

[10] Grant, W. S., Bowen, B. W. (1998): Shallow population histories in deep evolutionary lineages of marine fishes: insights from sardines and anchovies and lessons for conservation. - Journal of Heredity 89(5): 415-426.

[11] Guo, Y. W., Xie, X., Wang, B., Zhang, Y. Y., Xie, K. Z., Bu, X. N., Liu, C. J., Zhang, T., Zhang, G. X., Liu, X. Z., Dai, G. J. (2020): The establishment of a practical method for the determination of piperazine residues using accelerated solvent extraction and UHPLCFLD. - Quality Assurance and Safety of Crops \& Foods 12(1): 28-39.

[12] Haig, S. M., Ballou, J. D., Derrickson, S. R. (1990): Management options for preserving genetic diversity: reintroduction of guam rails to the wild. - Conservation Biology 4(3): 290-300.

[13] Hmwe, S. S., Zachos, F. E., Sale, J. B., Rose, H. R., Hartl, G. B. (2006): Genetic variability and differentiation in red deer (Cervus elaphus) from Scotland and England. - Journal of Zoology 270(3): 479-487.

[14] Hu, H. J., Xing, B., Yang, M., Mpemba, H., Lv, Z. H., Zhang, M. H. (2018): Population and genetic diversity of Tibetan red deer based on fecal DNA. - Journal of Forestry Research 29(1): 227-232.

[15] Huang, C. (2015): Comparative study on red deer winter nutritional strategy in Heilongjiang Muling and Inner Mongolia Gaogesitai National Nature Reserve, northeastern China. - Doctor's thesis, Northeast Forestry University, Harbin.

[16] Irwin, D. M., Kocher, T. D., Wilson, A. C. (1991): Evolution of the cytochrome b gene of mammals. - Journal of Molecular Evolution 32(2): 128-144.

[17] Kocher, T. D., Thomas, W. K., Meyer, A., Edwards, S. V., Pääbo, S., Villablanca, F. X., Wilson, A. C. (1989): Dynamics of mitochondrial DNA evolution in animals: amplification 
and sequencing with conserved primers. - Proceedings of the National Academy of Sciences of the United States of America 86(16): 6196-6200.

[18] Krojerová-Prokešová, J., Barančeková, M., Voloshina, I., Myslenkov, A., Lamka, J., Koubek, P. (2013): Dybowski's sika deer (Cervus nippon hortulorum): genetic divergence between natural Primorian and introduced Czech populations. - Journal of Heredity 104(3): 312-326.

[19] Larkin, M. A., Blackshields, G., Brown, N. P., Chenna, R., McGettigan, P. A., McWilliam, H., Valentin, F., Wallace, I. M., Wilm, A., Lopez, R. (2007): Clustal W and Clustal X version 2.0. - Bioinformatics 23(11): 2947-2948.

[20] Li, T., Jiang, J. S., Wu, Z. G., Han, X. D., Wu, J. C., Yang, X. J. (2001): Survey on Amur tiger in Jilin Province. - Acta Theriologica Sinica 21(1): 1-6.

[21] Li, Z. J., Chen, Y. H., Zhang, D. J., Zhang, G. F., Lu, B. X. (2019): Genetic diversity analysis and DNA fingerprinting of the main japonica rice varieties in Heilongjiang Province - Quality Assurance and Safety of Crops \& Foods 11(1): 23-29.

[22] Librado, P., Rozas, J. (2009): DnaSP v5: a software for comprehensive analysis of DNA polymorphism data. - Bioinformatics 25(11): 1451-1452.

[23] Liu, Y. H., Zhang, M. H. (2011): Population genetic diversity in Tibet red deer (Cervus elaphus wallichi) revealed by mitochondrial Cyt b gene analysis. - Acta Ecologica Sinica 31(7): 1976-1981.

[24] Liu, X. X. (2017): Study on the genetic diversity between the sympatric distribution of wild sika deer (Cervus nippon) and red deer (Cervus elaphus) in Muling based on faeces molecular biology. - Master's thesis, Northeast Forestry University, Harbin.

[25] Ma, Y., Li, H. L., He, J., Zhao, Y. M., Yang, H. Q., Lu, L., Liu, Q. Y. (2019): Genetic diversity and phylogenetic relationships based on mtDNA control region sequences of Marmota himalayana. - Acta Theriologica Sinica 39(3): 285-294.

[26] Mahmut, H., Anwar, T., Noriyuki, O. (2012): Tarim Red Deer of Xinjiang in China. Urumqi: Xinjiang University Press.

[27] Maruyama, T., Fuerst, P. A. (1985): Population bottlenecks and nonequilibrium models in population genetics. II. Number of alleles in a small population that was formed by a recent bottleneck. - Genetics 111(3): 675-689.

[28] Neigel, J. E., Avise, J. C. (1993): Application of a random walk model to geographic distributions of animal mitochondrial DNA variation. - Genetics 135(4): 1209-1220.

[29] Park, S. D. E. (2001): Trypanotolerance in west african cattle and the population genetic effects of selection. - PhD Thesis, University of Dublin.

[30] Peakall, R., Smouse, P. E. (2006): GENALEX 6: genetic analysis in Excel. Population genetic software for teaching and research. - Molecular Ecology Notes 6(1): 288-295.

[31] Pérez-Espona, S., Pérez-Barbería, F. J., Mcleod, J. E., Jiggins, C. D., Gordon, I. J., Pemberton, J. M. (2008): Landscape features affect gene flow of Scottish Highland red deer (Cervus elaphus). - Molecular ecology 17(4): 981-996.

[32] Pinilla, K., Hoinle, B., Mahecha-Groot, A., Cepeda, J. (2018): Mapping the agrodiversity in Bogotá-the platform mapeo AgroEcoBogotá. - International Journal of Design \& Nature and Ecodynamics 13(4): 407-414.

[33] Piry, S., Luikart, G., Cornuet, J. M. (1999): BOTTLENECK: a computer program for detecting recent reductions in the effective size using allele frequency data. - Journal of Heredity 90(4): 502-503.

[34] Pritchard, J. K., Stephens, M., Donnelly, P. (2000): Inference of population structure using multilocus genotype data. - Genetics 155(2): 945-959.

[35] Qi, J. Z., Shi, Q. H., Wang, G. M., Li, Z. L., Sun, Q., Hua, Y., Jiang, G. S. (2015): Spatial distribution drivers of Amur leopard density in northeast China. - Biological Conservation 191: 258-265.

[36] Qiao, F. J., Li, J. L., Gao, H., Teng, L. W., Wang, J. F., Liu, Z. S. (2019): Molecular phylogenetics of the Alashan red deer (Cervus elaphus alxaicus) based on Cyt b DNA. Chinese Journal of Wildlife 40(2): 307-311. 
[37] Randone, M., Bocci, M., Castellani, C., Laurent, C., Piante, C. (2019): Safeguarding marine protected areas in the growing Mediterranean blue economy- recommendations for the maritime transport sector. - International Journal of Design \& Nature and Ecodynamics 14(4): 264-274.

[38] Raymond, M., Rousset, F. (1995): GENEPOP (version 1.2): population genetics software for exact tests and ecumenicism. - Journal of Heredity 86(3): 248-249.

[39] Reinecke, H., Leinen, L., Thißen, I., Meißner, M., Herzog, S., Schütz, S., Kiffner, C. (2014): Home range size estimates of red deer in germany: environmental, individual and methodological correlates. - European Journal of Wildlife Research 60(2): 237-247.

[40] Sinnett, D., Jerome, G., Smith, N., Burgess, S., Mortlock, R. (2018): Raising the standard: Developing a benchmark for green infrastructure. - International Journal of Sustainable Development and Planning 13(2): 226-236.

[41] Speller, C. F., Kooyman, B., Rodrigues, A. T., Langemann, E. G., Jobin, R. M., Yang, D. Y. (2014): Assessing prehistoric genetic structure and diversity of North American elk (Cervus elaphus) populations in Alberta, Canada. - Canadian Journal of Zoology 92(4): 285-298.

[42] Taberlet, P., Griffin, S., Goossens, B., Questiau, S., Manceau, V., Escaravage, N., Waits, L. P., Bouvet, J. (1996): Reliable genotyping of samples with very low DNA quantities using PCR. - Nucleic Acids Research 24(16): 3189-3194.

[43] Tao, Y. X., Yan, D. R. (2014): Detection of parasite eggs from manure of semi-free Cervus elaphus in Gogostai Haan Nature Reserve of Inner Mongolia. - Animal Husbandry and Feed Science 35(10): 12-13.

[44] Tayerjan, M., Tajigul, T., Buweihailiqiemu, A., Subinur, E., Mahmut, H. (2018): Influence of environmental factors on genetic diversity of Tarim red deer. - Chinese Journal of Wildlife 39(4): 754-760.

[45] Tian, X. M., Zhang, M. H. (2010): Population size and sex ratio of wapiti (Cervus elephus xanthopygus) as revealed by fecal DNA. - Acta Ecologica Sinica 30(22): 6249-6254.

[46] Tian, X. M., Zhang, M. H., Zhang, H., Yang, C. W., Jin, Z. M. (2010): Genetic diversity of wapiti population in eastern Wandashan Mountains of Heilongjiang Province, China based on microsatellite analysis. - Chinese Journal of Ecology 29(3): 543-548.

[47] Tian, X. M., Wang, X. L., Zhang, M. H. (2019): Winter home range of the Manchurian wapiti (Cervus canadensis xanthopygus) based on noninvasive sampling. - Applied Ecology and Environmental Research 17(6): 15573-15583.

[48] Valière, N. (2002): Gimlet: a computer program for analysing genetic individual identification data. - Molecular Ecology Notes 2(3): 377-379.

[49] van Oosterhout, C., Hutchinson, W. F., Wills, D. P. M., Shipley, P. (2004): MICRO CHECKER: software for identifying and correcting genotyping errors in microsatellite data. - Molecular Ecology Notes 4(3): 535-538.

[50] Wang, S. (1998): China Red Data Book of Endangered Animals. - Beijing: Science Press.

[51] Xu, Q. X., Zhang, M. H., Lu, B. X. (2000): Study on the status of red deer population in Heilongjiang Province. - Journal of Economic Animal 4(1): 57-62.

[52] Yang, M., Sun, Y., Zhang, W. Q., Yuan, H. Y., Zhang, M. H. (2019): Variation in winter daily range area of red deer (Cervus elaphus xanthopygus) based on DNA extracted from fecal samples. - Journal of Forestry Research 30(5): 1951-1958.

[53] Yıldırım, A., Sönmezoğlu, Ö. A., Sayaslan, A., Kandemir, N., Gökmen, S. (2019): Molecular breeding of durum wheat cultivars for pasta quality. - Quality Assurance and Safety of Crops \& Foods 11(1): 15-21.

[54] Yuasa, T., Nagata, J., Hamasaki, S., Tsuruga, T., Furubayashi, K. (2007): The impact of habitat fragmentation on genetic structure of Japanese sika deer (Cervus nippon) in southern Kantoh, revealed by mitochondrial D-loop sequences. - Ecological Research 22(1): 97-106. 
[55] Zhang, S. L., Wang, Z. L., Zhang, P., Zhang, F., Yang, Y. X., He, W. (2009): Study on the status of wild red deer populations in Chifeng city, Inner Mongolia. - Sichuan Journal of Zoology 28(5): 772-776.

[56] Zhang, H. (2010): The individual identity, parentage analysis and home range determination of wapiti based on faeces molecular biology. - Master's thesis, Northeast Forestry University, Harbin.

[57] Zhang, M. H., Tian, X. M., Li, Y. (2010): A molecular identification and rapid recognition approach for the sex determination of wild wapiti by feces pellet morphology. - Acta Theriologica Sinica 30(3): 317-321.

[58] Zhang, C. Z., Zhang, M. H. (2011): Population status and dynamic trends of Amur tiger's prey in eastern Wandashan Mountains, Heilongjiang Province. - Acta Ecologica Sinica 31(21): 6481-6487.

[59] Zhang, L. B. (2016): Winter habitat spatial structure analysis and evaluation of red deer in Gaogesitai. - Master's thesis, Northeast Forestry University, Harbin.

[60] Zhou, C. L. (2015): The study on population size, genetic structure, home range and phylogeny of Tianshan red deer (Cervus elaphus songaricus). - Doctor's thesis, Xinjiang University, Urumqi.

[61] Zhou, S. C., Sun, H. Y., Yang, J., Huang, H. J. (2015): Study on population dynamic trends of Amur tiger's prey and impact factors in eastern Wandashan Mountains. - Forestry Science \& Technology 40(3): 37-40.

[62] Zorigul, I., Shamshinur, M., Buweihailiqiemu, A., Arzigul, S., Subinur, E., Mahmut, H. (2019): Influence of environmental factors on genetic diversity of Gazella subgotturosa in Xinjiang, China. - Acta Theriologica Sinica 39(3): 276-284.

\section{APPENDIX}

Table A1. GPS positions of 108 stool samples collected in the Gaogesitai region

\begin{tabular}{|c|c|c|}
\hline Sample number & Latitude & Longitude \\
\hline 1 & $44^{\circ} 57^{\prime} 17.358^{\prime \prime} \mathrm{N}$ & $119^{\circ} 30^{\prime} 12.660^{\prime \prime} \mathrm{E}$ \\
\hline 2 & $44^{\circ} 57^{\prime} 11.232^{\prime \prime} \mathrm{N}$ & $119^{\circ} 30^{\prime} 09.744^{\prime \prime} \mathrm{E}$ \\
\hline 3 & $44^{\circ} 57^{\prime} 30.396^{\prime \prime} \mathrm{N}$ & $119^{\circ} 28^{\prime} 38.592^{\prime \prime} \mathrm{E}$ \\
\hline 4 & $44^{\circ} 57^{\prime} 24.222^{\prime \prime} \mathrm{N}$ & $119^{\circ} 28^{\prime} 43.158^{\prime \prime E}$ \\
\hline 5 & $44^{\circ} 57^{\prime} 12.480^{\prime \prime} \mathrm{N}$ & $119^{\circ} 31^{\prime} 53.646^{\prime \prime E}$ \\
\hline 6 & $44^{\circ} 57^{\prime} 31.842^{\prime \prime} \mathrm{N}$ & $119^{\circ} 28^{\prime} 37.722^{\prime \prime E}$ \\
\hline 7 & $44^{\circ} 57^{\prime} 11.220^{\prime \prime} \mathrm{N}$ & $119^{\circ} 28^{\prime} 41.190^{\prime \prime E}$ \\
\hline 8 & $44^{\circ} 57^{\prime} 09.048^{\prime \prime} \mathrm{N}$ & $119^{\circ} 28^{\prime} 42.378^{\prime \prime E}$ \\
\hline 9 & $44^{\circ} 566^{\prime} 58.992^{\prime \prime N}$ & $119^{\circ} 28^{\prime} 31.596^{\prime \prime E}$ \\
\hline 10 & $44^{\circ} 57^{\prime} 03.174^{\prime \prime N}$ & $119^{\circ} 28^{\prime} 32.202^{\prime \prime E}$ \\
\hline 11 & $44^{\circ} 57^{\prime} 13.698^{\prime \prime} \mathrm{N}$ & $119^{\circ} 28^{\prime} 40.4944^{\prime \prime} \mathrm{E}$ \\
\hline 12 & $45^{\circ} 00^{\prime} 28.302^{\prime \prime} \mathrm{N}$ & $119^{\circ} 32^{\prime} 00.078^{\prime \prime E}$ \\
\hline 13 & $45^{\circ} 01 ' 53.418^{\prime \prime} \mathrm{N}$ & $119^{\circ} 33^{\prime} 09.690^{\prime \prime E}$ \\
\hline 14 & $45^{\circ} 00^{\prime} 27.108^{\prime \prime} \mathrm{N}$ & $119^{\circ} 31^{\prime} 59.208^{\prime \prime} \mathrm{E}$ \\
\hline 15 & $45^{\circ} 02^{\prime} 16.986^{\prime \prime} \mathrm{N}$ & $119^{\circ} 31^{\prime} 07.218^{\prime \prime} \mathrm{E}$ \\
\hline 16 & $45^{\circ} 02^{\prime} 16.890^{\prime \prime} \mathrm{N}$ & $119^{\circ} 31^{\prime} 07.308^{\prime \prime} \mathrm{E}$ \\
\hline 17 & $45^{\circ} 02^{\prime} 17.244^{\prime \prime} \mathrm{N}$ & $119^{\circ} 31^{\prime} 04.464^{\prime \prime} \mathrm{E}$ \\
\hline 18 & $45^{\circ} 02^{\prime} 17.484 \mathrm{~N}$ & $119^{\circ} 31^{\prime} 03.846^{\prime \prime E}$ \\
\hline 19 & $45^{\circ} 02^{\prime} 18.906^{\prime \prime} \mathrm{N}$ & $119^{\circ} 31^{\prime} 01.206^{\prime \prime E}$ \\
\hline 20 & $45^{\circ} 02^{\prime} 19.068^{\prime \prime} \mathrm{N}$ & $119^{\circ} 31^{\prime} 14.388^{\prime \prime} \mathrm{E}$ \\
\hline 21 & $45^{\circ} 01^{\prime} 42.288^{\prime \prime} \mathrm{N}$ & $119^{\circ} 32^{\prime} 52.020^{\prime \prime} \mathrm{E}$ \\
\hline 22 & $45^{\circ} 01^{\prime} 49.128^{\prime \prime} \mathrm{N}$ & $119^{\circ} 32^{\prime} 49.812^{\prime \prime} \mathrm{E}$ \\
\hline 23 & $45^{\circ} 01 ' 39.216 " \mathrm{~N}$ & $119^{\circ} 32^{\prime} 51.006^{\prime \prime E}$ \\
\hline 24 & $45^{\circ} 01^{\prime} 40.458^{\prime \prime} \mathrm{N}$ & $119^{\circ} 33^{\prime} 00.186^{\prime \prime E}$ \\
\hline 25 & $45^{\circ} 01^{\prime} 32.286^{\prime \prime} \mathrm{N}$ & $119^{\circ} 33^{\prime} 02.364 " \mathrm{E}$ \\
\hline 26 & $45^{\circ} 03^{\prime} 15.420^{\prime \prime} \mathrm{N}$ & $119^{\circ} 31^{\prime} 42.594 " \mathrm{E}$ \\
\hline 27 & $45^{\circ} 03^{\prime} 15.042^{\prime \prime} \mathrm{N}$ & $119^{\circ} 31^{\prime} 41.748^{\prime \prime E}$ \\
\hline 28 & $45^{\circ} 02^{\prime} 06.792^{\prime \prime} \mathrm{N}$ & $119^{\circ} 31^{\prime} 22.848^{\prime \prime E}$ \\
\hline 29 & $45^{\circ} 02^{\prime} 09.252^{\prime \prime} \mathrm{N}$ & $119^{\circ} 31^{\prime} 11.892^{\prime \prime E}$ \\
\hline
\end{tabular}




\begin{tabular}{|c|c|c|}
\hline 30 & $45^{\circ} 02^{\prime} 08.928^{\prime \prime} \mathrm{N}$ & $119^{\circ} 31^{\prime} 10.824 " \mathrm{E}$ \\
\hline 31 & $45^{\circ} 02^{\prime} 08.022^{\prime \prime N}$ & $119^{\circ} 31^{\prime} 01.080^{\prime \prime} \mathrm{E}$ \\
\hline 32 & $45^{\circ} 01^{\prime} 34.746 " \mathrm{~N}$ & $119^{\circ} 30^{\prime} 36.918^{\prime \prime E}$ \\
\hline 33 & $45^{\circ} 01^{\prime} 33.240 " \mathrm{~N}$ & $119^{\circ} 30^{\prime} 37.908^{\prime \prime E}$ \\
\hline 34 & $45^{\circ} 01^{\prime} 27.708^{\prime \prime} \mathrm{N}$ & $119^{\circ} 30^{\prime} 41.898^{\prime \prime} \mathrm{E}$ \\
\hline 35 & $45^{\circ} 01^{\prime} 18.174 " \mathrm{~N}$ & $119^{\circ} 30^{\prime} 55.302^{\prime \prime E}$ \\
\hline 36 & $45^{\circ} 01^{\prime} 18.504 " \mathrm{~N}$ & $119^{\circ} 30^{\prime} 57.900 " \mathrm{E}$ \\
\hline 37 & $45^{\circ} 01^{\prime} 18.642^{\prime \prime} \mathrm{N}$ & $119^{\circ} 31^{\prime} 00.132 " \mathrm{E}$ \\
\hline 38 & $45^{\circ} 01^{\prime} 18.702^{\prime \prime} \mathrm{N}$ & $119^{\circ} 31^{\prime} 01.878^{\prime \prime E}$ \\
\hline 39 & $44^{\circ} 57^{\prime} 22.458^{\prime \prime} \mathrm{N}$ & $119^{\circ} 27^{\prime} 22.074 " \mathrm{E}$ \\
\hline 40 & $44^{\circ} 56^{\prime} 31.806^{\prime \prime N}$ & $119^{\circ} 27^{\prime} 25.578^{\prime \prime E}$ \\
\hline 41 & $44^{\circ} 56^{\prime} 35.502^{\prime \prime} \mathrm{N}$ & $119^{\circ} 27^{\prime} 18.456^{\prime \prime E}$ \\
\hline 42 & $44^{\circ} 56^{\prime} 53.976^{\prime \prime N}$ & $119^{\circ} 27^{\prime} 19.104 " \mathrm{E}$ \\
\hline 43 & $44^{\circ} 57^{\prime} 05.712^{\prime \prime N}$ & $119^{\circ} 27^{\prime} 33.900 " \mathrm{E}$ \\
\hline 44 & $44^{\circ} 57^{\prime} 15.834^{\prime \prime N}$ & $119^{\circ} 27^{\prime} 35.268^{\prime \prime E}$ \\
\hline 45 & $45^{\circ} 01^{\prime} 42.966 " \mathrm{~N}$ & $119^{\circ} 32^{\prime} 51.888^{\prime \prime E}$ \\
\hline 46 & $45^{\circ} 01^{\prime} 55.512^{\prime \prime} \mathrm{N}$ & $119^{\circ} 32^{\prime} 39.858^{\prime \prime E}$ \\
\hline 47 & $45^{\circ} 02^{\prime} 06.642^{\prime \prime} \mathrm{N}$ & $119^{\circ} 32^{\prime} 46.404^{\prime \prime E}$ \\
\hline 48 & $45^{\circ} 02^{\prime} 06.552^{\prime \prime} \mathrm{N}$ & $119^{\circ} 32^{\prime} 46.788^{\prime \prime E}$ \\
\hline 49 & $44^{\circ} 58^{\prime} 03.150^{\prime \prime} \mathrm{N}$ & $119^{\circ} 28^{\prime} 14.688^{\prime \prime E}$ \\
\hline 50 & $44^{\circ} 58^{\prime} 05.604^{\prime \prime} \mathrm{N}$ & $119^{\circ} 28^{\prime} 21.840^{\prime \prime E}$ \\
\hline 51 & $44^{\circ} 58^{\prime} 07.110^{\prime \prime} \mathrm{N}$ & $119^{\circ} 28^{\prime} 22.632^{\prime \prime E}$ \\
\hline 52 & $44^{\circ} 58^{\prime} 12.696^{\prime \prime} \mathrm{N}$ & $119^{\circ} 28^{\prime} 26.682^{\prime \prime E}$ \\
\hline 53 & $44^{\circ} 58^{\prime} 12.522^{\prime \prime} \mathrm{N}$ & $119^{\circ} 28^{\prime} 15.042^{\prime \prime E}$ \\
\hline 54 & $44^{\circ} 58^{\prime} 10.068^{\prime \prime} \mathrm{N}$ & $119^{\circ} 28^{\prime} 14.994 " \mathrm{E}$ \\
\hline 55 & $44^{\circ} 57^{\prime} 37.338^{\prime \prime N} \mathrm{~N}$ & $119^{\circ} 26^{\prime} 30.000^{\prime \prime} \mathrm{E}$ \\
\hline 56 & $44^{\circ} 57^{\prime} 36.378^{\prime \prime N}$ & $119^{\circ} 26^{\prime} 33.150^{\prime \prime} \mathrm{E}$ \\
\hline 57 & $44^{\circ} 57^{\prime} 36.354^{\prime \prime} \mathrm{N}$ & $119^{\circ} 26^{\prime} 35.706^{\prime \prime E}$ \\
\hline 58 & $44^{\circ} 57^{\prime} 35.394^{\prime \prime N}$ & $119^{\circ} 26^{\prime} 40.098^{\prime \prime E}$ \\
\hline 59 & $44^{\circ} 57^{\prime} 22.074^{\prime \prime N}$ & $119^{\circ} 26^{\prime} 59.544 " \mathrm{E}$ \\
\hline 60 & $44^{\circ} 57^{\prime} 19.734^{\prime \prime} \mathrm{N}$ & $119^{\circ} 27^{\prime} 11.136 " \mathrm{E}$ \\
\hline 61 & $44^{\circ} 57^{\prime} 22.920^{\prime \prime} \mathrm{N}$ & $119^{\circ} 27^{\prime} 12.942 " \mathrm{E}$ \\
\hline 62 & $45^{\circ} 03^{\prime} 30.078^{\prime \prime} \mathrm{N}$ & $119^{\circ} 32^{\prime} 31.230^{\prime \prime} \mathrm{E}$ \\
\hline 63 & $45^{\circ} 03^{\prime} 26.706^{\prime \prime} \mathrm{N}$ & $119^{\circ} 32^{\prime} 30.966 " \mathrm{E}$ \\
\hline 64 & $45^{\circ} 03^{\prime} 18.780 " \mathrm{~N}$ & $119^{\circ} 32^{\prime} 32.796 " \mathrm{E}$ \\
\hline 65 & $45^{\circ} 03^{\prime} 16.356^{\prime \prime} \mathrm{N}$ & $119^{\circ} 32^{\prime} 32.454^{\prime \prime E}$ \\
\hline 66 & $45^{\circ} 03^{\prime} 14.370^{\prime \prime} \mathrm{N}$ & $119^{\circ} 32^{\prime} 34.524^{\prime \prime E}$ \\
\hline 67 & $45^{\circ} 03^{\prime} 11.430 " \mathrm{~N}$ & $119^{\circ} 32^{\prime} 39.384 " \mathrm{E}$ \\
\hline 68 & $45^{\circ} 03^{\prime} 11.514 " \mathrm{~N}$ & $119^{\circ} 32^{\prime} 47.256^{\prime \prime E}$ \\
\hline 69 & $45^{\circ} 03^{\prime} 12.060 " \mathrm{~N}$ & $119^{\circ} 32^{\prime} 51.036^{\prime \prime E}$ \\
\hline 70 & $45^{\circ} 03^{\prime} 19.818^{\prime \prime} \mathrm{N}$ & $119^{\circ} 32^{\prime} 50.850^{\prime \prime} \mathrm{E}$ \\
\hline 71 & $45^{\circ} 03^{\prime} 25.194 " \mathrm{~N}$ & $119^{\circ} 32^{\prime} 50.532^{\prime \prime E}$ \\
\hline 72 & $45^{\circ} 03^{\prime} 26.394 " \mathrm{~N}$ & $119^{\circ} 32^{\prime} 43.068^{\prime \prime E}$ \\
\hline 73 & $45^{\circ} 00^{\prime} 58.326^{\prime \prime} \mathrm{N}$ & $119^{\circ} 31^{\prime} 36.498^{\prime \prime E}$ \\
\hline 74 & $45^{\circ} 01^{\prime} 07.266^{\prime \prime} \mathrm{N}$ & $119^{\circ} 31^{\prime} 19.884 " \mathrm{E}$ \\
\hline 75 & $45^{\circ} 01^{\prime} 09.072^{\prime \prime} \mathrm{N}$ & $119^{\circ} 31^{\prime} 03.126^{\prime \prime E}$ \\
\hline 76 & $45^{\circ} 01^{\prime} 13.164 " \mathrm{~N}$ & $119^{\circ} 31^{\prime} 00.150^{\prime \prime} \mathrm{E}$ \\
\hline 77 & $45^{\circ} 01^{\prime} 13.380^{\prime \prime} \mathrm{N}$ & $119^{\circ} 30^{\prime} 54.984 " \mathrm{E}$ \\
\hline 78 & $45^{\circ} 01^{\prime} 16.488^{\prime \prime} \mathrm{N}$ & $119^{\circ} 31^{\prime} 00.360 " \mathrm{E}$ \\
\hline 79 & $45^{\circ} 02^{\prime} 05.478^{\prime \prime} \mathrm{N}$ & $119^{\circ} 31^{\prime} 48.798^{\prime \prime E}$ \\
\hline 80 & $45^{\circ} 02^{\prime} 08.778^{\prime \prime} \mathrm{N}$ & $119^{\circ} 31^{\prime} 56.544 " \mathrm{E}$ \\
\hline 81 & $44^{\circ} 59^{\prime} 03.582^{\prime \prime} \mathrm{N}$ & $119^{\circ} 31^{\prime} 32.580^{\prime \prime} \mathrm{E}$ \\
\hline 82 & $44^{\circ} 59^{\prime} 03.720^{\prime \prime} \mathrm{N}$ & $119^{\circ} 31^{\prime} 31.590 " \mathrm{E}$ \\
\hline 83 & $44^{\circ} 59^{\prime} 04.704 " \mathrm{~N}$ & $119^{\circ} 31^{\prime} 25.326^{\prime \prime} \mathrm{E}$ \\
\hline 84 & $44^{\circ} 59^{\prime} 04.572^{\prime \prime} \mathrm{N}$ & $119^{\circ} 31^{\prime} 21.870^{\prime \prime} \mathrm{E}$ \\
\hline 85 & $44^{\circ} 59^{\prime} 09.354^{\prime \prime} \mathrm{N}$ & $119^{\circ} 31^{\prime} 14.934 " \mathrm{E}$ \\
\hline 86 & $44^{\circ} 59^{\prime} 18.438^{\prime \prime} \mathrm{N}$ & $119^{\circ} 31^{\prime} 09.984 " \mathrm{E}$ \\
\hline 87 & $44^{\circ} 59^{\prime} 23.094^{\prime \prime} \mathrm{N}$ & $119^{\circ} 31^{\prime} 11.892 " \mathrm{E}$ \\
\hline 88 & $44^{\circ} 58^{\prime} 44.988^{\prime \prime} \mathrm{N}$ & $119^{\circ} 26^{\prime} 03.402^{\prime \prime E}$ \\
\hline 89 & $44^{\circ} 58^{\prime} 58.662^{\prime \prime} \mathrm{N}$ & $119^{\circ} 26^{\prime} 02.724^{\prime \prime E}$ \\
\hline 90 & $44^{\circ} 59^{\prime} 00.222^{\prime \prime} \mathrm{N}$ & $119^{\circ} 26^{\prime} 03.816^{\prime \prime E}$ \\
\hline 91 & $44^{\circ} 59^{\prime} 01.260^{\prime \prime} \mathrm{N}$ & $119^{\circ} 26^{\prime} 02.802^{\prime \prime E}$ \\
\hline 92 & $44^{\circ} 59^{\prime} 19.806^{\prime \prime N}$ & $119^{\circ} 26^{\prime} 19.692^{\prime \prime E}$ \\
\hline 93 & $44^{\circ} 59^{\prime} 11.232^{\prime \prime} \mathrm{N}$ & $119^{\circ} 26^{\prime} 37.944 " \mathrm{E}$ \\
\hline
\end{tabular}




\begin{tabular}{|c|c|c|}
\hline 94 & $45^{\circ} 00^{\prime} 11.118^{\prime \prime} \mathrm{N}$ & $119^{\circ} 26^{\prime} 55.830^{\prime \prime E}$ \\
\hline 95 & $44^{\circ} 57^{\prime} 23.394 " \mathrm{~N}$ & $119^{\circ} 27^{\prime} 40.614^{\prime \prime} \mathrm{E}$ \\
\hline 96 & $44^{\circ} 57^{\prime} 21.768^{\prime \prime N}$ & $119^{\circ} 27^{\prime} 46.140^{\prime \prime E}$ \\
\hline 97 & $44^{\circ} 57^{\prime} 26.436 " \mathrm{~N}$ & $119^{\circ} 28^{\prime} 20.694^{\prime \prime E}$ \\
\hline 98 & $44^{\circ} 57^{\prime} 29.112^{\prime \prime N}$ & $119^{\circ} 29^{\prime} 03.222^{\prime \prime E}$ \\
\hline 99 & $44^{\circ} 57^{\prime} 44.682^{\prime \prime N}$ & $119^{\circ} 28^{\prime} 12.600^{\prime \prime E}$ \\
\hline 100 & $44^{\circ} 57^{\prime} 47.304^{\prime \prime} \mathrm{N}$ & $119^{\circ} 28^{\prime} 13.470^{\prime \prime} \mathrm{E}$ \\
\hline 101 & $44^{\circ} 58^{\prime} 02.616^{\prime \prime} \mathrm{N}$ & $119^{\circ} 28^{\prime} 12.720^{\prime \prime} \mathrm{E}$ \\
\hline 102 & $44^{\circ} 58^{\prime} 07.758^{\prime \prime N}$ & $119^{\circ} 28^{\prime} 15.198^{\prime \prime} \mathrm{E}$ \\
\hline 103 & $44^{\circ} 58^{\prime} 08.376^{\prime \prime N}$ & $119^{\circ} 28^{\prime} 15.612^{\prime \prime} \mathrm{E}$ \\
\hline 104 & $44^{\circ} 58^{\prime} 11.052^{\prime \prime N}$ & $119^{\circ} 28^{\prime} 15.414^{\prime \prime E}$ \\
\hline 105 & $44^{\circ} 58^{\prime} 10.896 " \mathrm{~N}$ & $119^{\circ} 28^{\prime} 11.616^{\prime E} \mathrm{E}$ \\
\hline 106 & $44^{\circ} 58^{\prime} 06.510^{\prime \prime} \mathrm{N}$ & $119^{\circ} 28^{\prime} 02.718^{\prime \prime E}$ \\
\hline 107 & $44^{\circ} 58^{\prime} 05.424 " \mathrm{~N}$ & $119^{\circ} 28^{\prime} 01.236^{\prime \prime E}$ \\
\hline 108 & $44^{\circ} 58^{\prime} 00.702^{\prime \prime N}$ & $119^{\circ} 27^{\prime} 50.928^{\prime \prime E}$ \\
\hline
\end{tabular}

